\title{
Evaluation of Antimicrobial Activity of Water Infusion Plant-Mediated Silver Nanoparticles
}

\author{
Omar El-Shahaby ${ }^{1}$, Mustafa El-Zayat ${ }^{2 *}$, Ehab Salih ${ }^{3}$, Ibrahim M El-Sherbiny ${ }^{4,5}$ and Fikry M Reicha ${ }^{3}$
}

${ }^{1}$ Botany Department, Faculty of Science, Mansoura University, ET-35516, Mansoura, Egypt

${ }^{2}$ Unit of Genetic Engineering and Biotechnology, Faculty of Science, Mansoura University, Egypt

${ }^{3}$ Biological Advanced Materials, Physics Department, Faculty of Science, Mansoura University, Egypt

${ }^{4}$ Zewail University, Zewail City of Science and Technology, 6 ${ }^{\text {th }}$, October City, 12588 Giza, Egypt

${ }^{5}$ Chemistry Department, Faculty of Science, Mansoura University, ET-35516, Mansoura, Egypt

\begin{abstract}
Phytochemical analysis revealed that the infusion of Rumex dentatus is rich in flavonoids, phenolics, reducing sugars and total sugars. The plant infusion found to possess a significant antioxidant activity. The aqueous extract of Rumex dentatus has been used as a green reducing and stabilizing agent in addition to its desirable biological activity. The biosynthesis of reduced silver nanoparticles was very fast, and silver nanoparticles were synthesized by exposure of a mixture of different ratios of $4 \mathrm{mM} \mathrm{AgNO}_{3}$ and Rumex dentatus aqueous extract to UV-irradiation at room temperature. Ultraviolet-visible absorption spectroscopy, transmission electron microscopy and X-ray diffraction confirmed reduction of $\mathrm{Ag}^{+}$ions and formation of silver nanoparticles. Varied morphology of the bioreduced silver nanoparticles was recorded. On contrast to the main plant infusion, the resulting silver nanoparticles were found to possess wide spectrum of antimicrobial activity increasing proportionally with the increase of the concentration of the silver nanoparticles against wide variety of bacterial and fungal pathogenic strains.
\end{abstract}

Keywords: Antimicrobial activity; Phenolics; Flavonoids; Antioxidant; Silver nanoparticles

\section{Introduction}

Nanoparticles are atomic or molecular aggregates with at least one dimension between 1 and 100nm [1-3], that can drastically modify their physico-chemical properties compared to the bulk material $[3,4]$. Nanoparticles can be made from a variety of bulk materials and can explicate their actions depending on the chemical composition and on the size and/or shape of the particles [3,5]. Nanostructure materials have generated intense scientific and technological interest because of their potential applications in areas as diverse as electronics, optics, sensors, information and communication technology, transparent sunscreen lotions, stain-resistant fabrics, scratch free paints for cars, products labeling, textiles, biomedicine, health care, antibacterial dressings [6,7].

The noble metal nanoparticles such as gold $(\mathrm{Au})$, platinum $(\mathrm{Pt})$ and silver (Ag) nanoparticles have gained a considerable interest over the last decade owing to their important applications [8-11]. It is now well understood that the intrinsic characteristics of noble metal nanoparticles are dependent on their composition, size, crystallinity, shape, and structure (either hollow or solid) [12]. Ag nanoparticles are excellent components for the Surface Enhanced Raman Scattering (SERS) to probe single molecules [13], in addition to their desirable role as catalysts for accelerating some chemical reactions [14]. Moreover, they have been used in other various applications as antimicrobial, electrical conducting, and in sensing/optical applications [15].

An important branch of biosynthesis of nanoparticles is the application of plant extracts to the biosynthesis reaction. With increasing focus on green chemistry, natural compounds like glucose (16), chitosan [17], soluble starch [18] and some microorganisms [19-22], etc., have attracted considerable research interest as safer alternatives, reducing and stabilizing agents to synthesize the silver nanosphere. Synthesis of nanoparticles through biochemical routes, using plant extracts as reducing and capping agents, has received special attention among others, due to maintaining an aseptic environment during the process [23-29]. Therefore, medicinal plants having well established therapeutic importance are being widely used for the sizeand shape-controlled synthesis of silver nanoparticles [30-33].

Rumex dentatus L. (Polygonaceae) is a weedy plant known as toothed dock. It is widely distributed in many countries including Egypt. It occurs in waste places, shores and cultivated fields. It has been used as a leafy vegeTable in the Mediterranean diet. It responds to unfavourable environmental conditions by including Reactive Oxygen Species (ROS) and malonyldialdehyde [34-38]. Its leaves are diuretic, refrigerant, and used as cooling agent, while the roots are used as an astringent and in cutaneous disorders [38-40]. It showed antibacterial, antifungal, insecticidal, molluscicidal, antitumor, astringent, antiinflammatory, antidermatistis and allelopathic activities [37,41-46]. Its roots are used in folk medicine for treating acariasis, eczema, diarrhea and contisipation $[37,47]$. Previous phytochemical studies on Rumex dentatus have demonstrated the presence of anthraquinones, flavonoids, phytosterols, phytoesteryl esters, free fatty acids, chromones and anthrones $[37,48,49]$. Furthermore, some phenolics have been detected in $R$. dentatus $[38,41,50]$.

\section{Materials and Methods}

\section{Plant material and Preparation of the infusion}

The aerial parts of the wild Rumex dentatus plants were collected

*Corresponding author: Mustafa Mohsen El Zayat, Faculty of Science Mansoura University, ET-35516 Mansoura, Al Dakahlia, Egypt, E-mail: mzayat2001@yahoo.com

Received April 23, 2013; Accepted July 27, 2013; Published July 27, 2013

Citation: El-Shahaby O, El-Zayat M, Salih E, El-Sherbiny IM, Reicha FM (2013) Evaluation of Antimicrobial Activity of Water Infusion Plant-Mediated Silver Nanoparticles. J Nanomed Nanotechol 4: 178. doi:10.4172/2157-7439.1000178

Copyright: ( $2013 \mathrm{El}$-Shahaby O, et al. This is an open-access article distributed under the terms of the Creative Commons Attribution License, which permits unrestricted use, distribution, and reproduction in any medium, provided the original author and source are credited. 
from their original habitates Mansoura, Egypt. The plant was taxonomically identified according to Boulos [51].

Fresh parts of Rumex dentatus were washed thoroughly and chopped into fine pieces. About $20 \mathrm{gm}$ of the chopped Rumex dentatus were transferred into a $500 \mathrm{ml}$ Erlenmeyer flask containing $100 \mathrm{ml}$ deionized water, mixed well, and boiled for 10 minutes in water bath at $80^{\circ} \mathrm{C}$. The extract obtained was filtered through Whatman no. 1 filter paper, and the filtrate was collected and stored at $4^{\circ} \mathrm{C}$ for further use.

A part of the plant material was air dried in shadow for 15-20 days and then grinded into fine powder for phytochemical analysis.

\section{Phytochemical analysis}

Determination of total phenolic compounds: The determination of total phenolic compounds in the extracts was carried out using Folin Ciocalteu method developed by Wolfe et al. [52].

Gallic acid was used as a standard, where total phenolics content expressed as mg gallic acid equivalent $/ 100 \mathrm{~g}$ dried plant material.

Determination of total flavonoids content: The total flavonoids were determinate using aluminum chloride colorimetric assay developed by Zhishen et al. [53].

Catechin was used as a standard, where total flavonoids content expressed as $\mathrm{mg}$ catechin equivalent $/ 100 \mathrm{~g}$ dried plant material.

Determination of the radical scavenging activity using DPPH assay: The antioxidant activity was estimated by the Free radical scavenging method (DPPH) as described by Kitts et al. [54] with slight modifications by Liyana- Pathirana et al. [55] and Parejo et al. [56].

Gallic acid, catechin and ascorbic acid were used as standards.

Total soluble sugars and total carbohydrates content: Carbohydrates content and total soluble sugars were determined spectrophometrically using the method describd by Thayumanavan and Sadasivam [57].

Glucose was used as a standard, where total soluble sugars and carbohydrates content were expressed as g glucose equivalent $/ 100 \mathrm{~g}$ dried plant material.

\section{Synthesis of silver nanoparticles}

Aqueous silver nitrate solution $(4 \mathrm{mM})$ was prepared and used for the synthesis of a series of silver nanoparticles in presence of the prepared Rumex dentatus water extract upon exposure of the mixture to $\mathrm{UV}$ irradiation as a reducing agent for the $\mathrm{Ag}^{+}$ions. Different v/v ratios of the extract and the aqueous $\mathrm{AgNO}_{3}$ solution were mixed thoroughly $(15: 60,25: 50,37.5: 37.5,50: 25$, and 60:15) and the mixtures were subjected to UV-irradiation using different time intervals from 2 min up to $10 \mathrm{~min}$.

\section{Instrumental analysis}

ATI Unicom UV-Vis. Spectrophotometer: The reduction of pure $\mathrm{Ag}^{+}$ions into silver nanoparticles was monitored by recording the UVVis spectra of the reaction mixture at different time intervals. The UVVisible spectra of the resulting silver nanoparticles were recorded in the range of 200-800 nm using ATI Unicom UV-Vis. spectrophotometer with the aid of ATI Unicom UV-Vis. vision software V 3.20. The analysis was performed at room temperature using quartz cuvettes (1 $\mathrm{cm}$ optical path), and the blank was the corresponding Rumex dentatus aqueous solution.
Fourier transform infrared spectroscopy: FT-IR measurements were carried out for both the Rumex dentatus aqueous extract and the silver nanoparticles synthesized in the presence of the Rumex dentatus to identify the possible biomolecules in the Rumex dentatus extract that can participate in the reduction process of the $\mathrm{Ag}^{+}$ions and capping of the resulting silver nanoparticles. The samples were dried and grinded with $\mathrm{KBr}$ pellets and analyzed on Mattson 5000 FTIR spectrometer in the range of $400-4000 \mathrm{~cm}^{-1}$ at a resolution of $8 \mathrm{~cm}^{-1}$ at $25^{\circ} \mathrm{C}$.

Transmission electron microscope measurement: The size and morphology of the resulting silver nanoparticles was investigated by transmission electron microscopy, TEM (JEOL TEM-1230) attached to a CCD camera at an accelerating voltage of $120 \mathrm{kV}$. The samples were prepared by placing few drops of the nanoparticles suspension on carbon coated copper grids, followed by allowing the solvent to slowly evaporate under the sun light before recording the TEM images.

\section{Microbial susceptibility testing}

The antimicrobial activity of the plant infusion was estimated by filter paper disc method (9) using inoculums containing $10^{6}$ bacterial and fungal cells or $10^{8}$ yeast cells $/ \mathrm{ml}$ to spread on nutrient agar, Czapek Dox agar and Sabouraud agar plates, respectively.

The sterilised filter paper discs (Whatman no.1, $6 \mathrm{~mm}$ in diameter) were saturated with infusion obtained from the plant and another set of filter paper discs were soaked in water served as controls. The discs were placed on the surface of agar plates seeded with the test organisms. The plates were incubated at $28^{\circ} \mathrm{C}$ for fungi, at $37^{\circ} \mathrm{C}$ for bacteria and at $30^{\circ} \mathrm{C}$ for yeast. Diameters of inhibition zone $(\mathrm{mm})$ were measured after 1824 hours for bacteria, 24-48 hours for yeast and 4-7 days for fungi [58].

Paper discs impregnated with $20 \mu \mathrm{l}$ of a solution of $10 \mathrm{mg} / \mathrm{ml}$ of Ampicillin, Penicillin and Tobramycin (for bacteria) and Nystatin and Clotrimazole (for fungi) as standard antimicrobials were used for comparison.

\section{Tested organisms}

Bacteria: Staphylococcus aureus, Staphylococcus epidermis, Streptococcus pyogenes, Pseudomonas aeruginosa, Klebsiella pneumonia, Shigells spp., E. coli, Proteus vulgaris.

Fungi: Aspergillus niger, Erwenia carotovora, Fusarium solani, Asperigillus flaviries, Asperigillus ochraceous and Trichothecium spp.

Stock cultures of the tested organisms were obtained from the microbiological lab at Faculty of Medicine in Mansoura University.

\section{Results}

\section{Phytochemical analysis}

Rumex dentatus is well known to be rich in diverse phytochemicals like phenolics, flavonoids, carbohydrates, and vitamins that might play a significant role in bioreduction of silver nanoparticles.

\section{Total phenolics content}

The phenolic compounds, ubiquitous in plants are an essential part of the human diet and are of considerable interest due to their antioxidant properties. The antioxidant activity of phenolic compounds depends on the structure, in particular the number and positions of the hydroxyl groups and the nature of substitutions on the aromatic rings $[59,60]$.

The total phenolic compounds of the Rumex dentatus examined 
Citation: El-Shahaby O, El-Zayat M, Salih E, El-Sherbiny IM, Reicha FM (2013) Evaluation of Antimicrobial Activity of Water Infusion Plant-Mediated Silver Nanoparticles. J Nanomed Nanotechol 4: 178. doi:10.4172/2157-7439.1000178

infusion, was reported as gram of gallic acid equivalents/100 gram of the dried plant material with reference to the standard curve $(y=0.0063 x$, $\left.\mathrm{r}^{2}=0.987\right)$. The total phenolics content was $175 \pm 4.20 \mathrm{mg}$ gallic acid equivalent per gram of Rumex dentatus extract and $2.70 \pm 0.05$ gram of gallic acid equivalents/100 gram of the dried plant material.

\section{The total Flavonoids content}

The total Flavonoids content were expressed as gram catechine equivalent per 100 gram of the dried plant material by reference to standard curve $\left(y=0.003 \times, r^{2}=0.994\right)$. Among the different plant extracts, the total flavonoids contents was $43.75 \pm 1.30 \mathrm{mg}$ catechine equivalent per gram of Rumex dentatus extract and $0.675 \pm 0.013$ gram of gallic acid equivalents/100 gram of the dried plant material.

\section{Evaluation of the antioxidant activity of the plants water infusions}

The free radical scavenging activity using DPPH assay: The concentration of an antioxidant needed to decrease the initial DPPH concentration by $50 \%$ (EC50) is a parameter widely adopted to measure the antioxidant activity [61]. The lower the EC50, the higher the antioxidant power. Another parameter was defined as antiradical efficiency $(\mathrm{AE}=1 / \mathrm{EC} 50)$ or antiradical power (ARP) was used [62]. The higher the AE, the higher the antioxidant activity. Catechine, ascorbic acid and gallic acid were employed as reference compounds in this experiment. EC50 value is calculated as $\mathrm{mg}$ of the tested extract or compound/ $\mathrm{mg}$ of DPPH where the inhibition of test activity reached $50 \%$ using the exponential curve obtained from plotting the DPPH \% against mg sample/mg DPPH.

The water extract of the wild $R$. dentatus plants showed EC50 $=3.23$ $\mathrm{mg}$ extract $/ \mathrm{mg} \mathrm{DPPH}$ and $\mathrm{AE}=0.134$. Catechine, ascorbic acid and gallic acid showed EC50 $=0.268,0.610$ and $0.525 \mathrm{mg}$ extract $/ \mathrm{mg} \mathrm{DPPH}$ and $\mathrm{AE}=3.73,1.64$ and 1.91 , respectively.

\section{Total soluble sugars and total carbohydrates content}

The total soluble sugars and total carbohydrates were $2.61 \pm 0.25$ and $3.26 \pm 0.02$ gram glucose equivalent/100 gram of the dried plant material, respectively (Figure 1).

\section{Synthesis of nanoparticles}

The well known yellowish brown color of silver nanoparticles arises due to excitation of Surface Plasmon Resonance (SPR) with an absorption maxima at $460 \mathrm{~nm}$.

UV-Vis spectroscopy: The synthesis of the silver nanoparticles has been confirmed by measuring the UV-Vis spectra of the reaction mixture (Figure 2). As apparent from Figure 2, the absorption peak appeared at about $460 \mathrm{~nm}$ is corresponding to the characteristic surface plasmon resonance of the resulting Ag NPs. The silver nanoparticles formed employing R. dentatus extract were found to be very sTable, possibly because of the starch present in the extract that prevented agglomeration (Figure 2).

FTIR spectroscopy: FTIR analysis was carried out in order to identify the possible reducing and stabilizing biomolecules, described in Figure 1, in the Rumex dentatus extract. FTIR absorption spectra of $R$. dentatus water extract before and after reduction of silver are shown in Figure 3. FTIR spectrum of Rumex dentatus extract shows bands at $517,773,825,1078,1384,1635$ and $3432 \mathrm{~cm}^{-1}$. The band around 1078 $\mathrm{cm}^{-1}$ corresponds to the $\mathrm{C}-\mathrm{O}$ stretching vibration whereas, the band appeared at about $1635 \mathrm{~cm}^{-1}$ can be assigned for aromatic rings. The strong broad band appearing at $3432 \mathrm{~cm}^{-1}$ can be associated to the stretching vibrations of alcoholic and phenolic $\mathrm{O}-\mathrm{H}$ (Figure 3).

Transmission electron microscopy: Transmission electron microscopy (TEM) has been utilized to characterize the size and morphology of the formed silver nanoparticles. Figure 4 shows the TEM micrographs of the silver nanoparticles developed from a Rumex dentatus and $\mathrm{AgNO}_{3}$ after UV-irradiation reduction. From the Figure, the obtained nanoparticles are predominantly spherical, polydispersed and are surrounded by a thin layer of organic material which tends

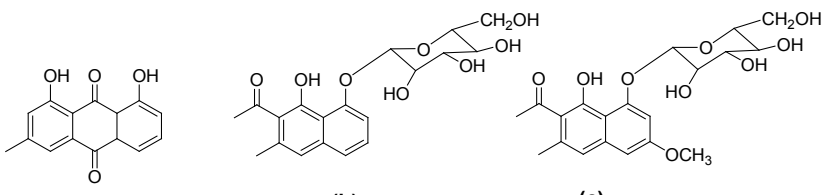

(a)

(b)

(c)

Figure 1: The chemical structure of the three main compounds in the Rumex dentatus extract.

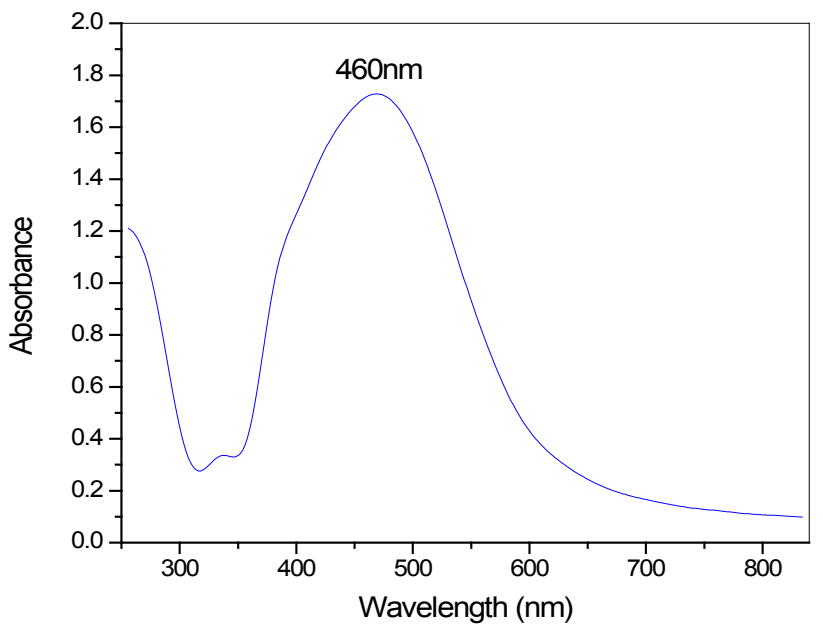

Figure 2: UV-vis spectra of Ag nanoparticles recorded as a function of reaction time.

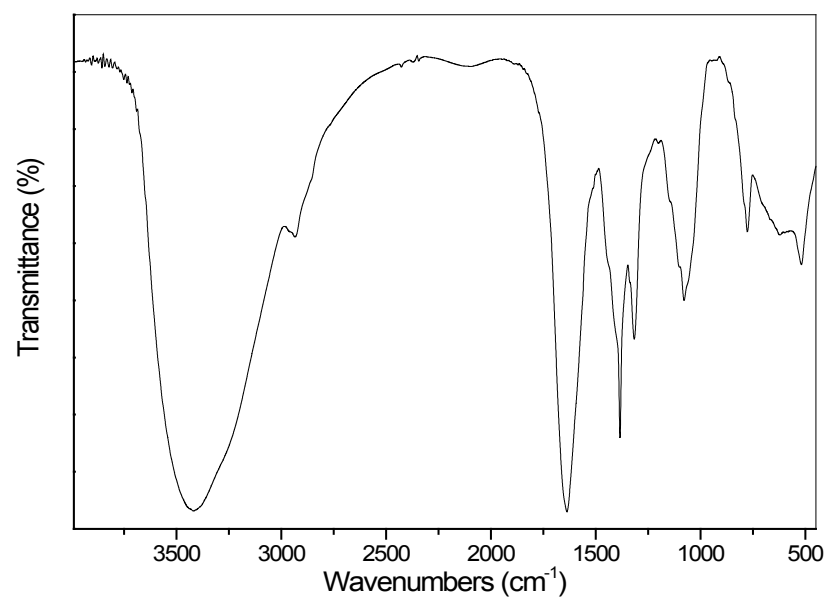

Figure 3: FTIR spectrum of Rumex Dentatus extract. 
Citation: El-Shahaby O, El-Zayat M, Salih E, El-Sherbiny IM, Reicha FM (2013) Evaluation of Antimicrobial Activity of Water Infusion Plant-Mediated Silver Nanoparticles. J Nanomed Nanotechol 4: 178. doi:10.4172/2157-7439.1000178

Page 4 of 7

to be characteristic of silver nanoparticles developed in plant extracts. the Figure also propose the presence of two distinct size regions, small nanoparticles with diameters in the range between 5 and $18 \mathrm{~nm}$ and larger particles of about $30 \mathrm{~nm}$ sizes.

In order to verify the crystalline nature of the nanoparticles the selected area electron diffraction (SAED) patterns were obtained for the sample containing $4 \mathrm{mM}$ of $\mathrm{AgNO}_{3}$. The presence of bright circular rings in the SAED patterns confirms the crystalline nature of the silver nanoparticles. The spots corresponding to various orientations appearing inside the concentric rings also show that the obtained silver nanoparticles has a good crystallinity [63].

\section{Evaluation of the antimicrobial activity}

Microbial Susceptibility Testing (Disc diffusion assay): Silver is well known as one of the most universal antimicrobial substances. The results of the antimicrobial activity of wild Rumex dentatus water extracts and the prepared silver nanoparticles using different $\mathrm{v} / \mathrm{v}$ ratios of the water extract and the aqueous $\mathrm{AgNO}_{3}$ solution (15:60, 25:50, $37.5: 37.5,50: 25$, and 60:15) that were mixed thoroughly and subjected to UV-irradiation tested against pathogenic microbial strains by disc diffusion assay are summarized in Table1.
The water extract of wild $R$. dentatus plants was found to possess antimicrobial spectrum against Staphylococcus epidermis, Klebsiella pneumonia and E. coli.

As the percent of synthesized silver nanoparticles increased as the antimicrobial spectrum increased. The silver nanoparticles synthesized from the mixture with the ratio $4 \mathrm{AgNO}_{3}: 1 \mathrm{R}$. dentatus water extract showed the broadest antimicrobial spectrum against the tested pathogenic strains among all the other prepared extracts as shown in Table 1 and Figure 5.

\section{Discussion}

We have successfully demonstrated a rapid and efficient route for synthesis of silver nanoparticles using $R$. dentatus extract. The development of yellowish brown color owing to the surface Plasmon resonance with absorption maxima at $460 \mathrm{~nm}$ confirmed the formation of silver nanoparticles [64,65]. $R$. dentatus is a rich source of flavonoids and phenolics. Flavonoids play a vital role in the reduction process for synthesis of silver nanoparticles $[65,66]$. Thus the high flavonoid and phenolics content in $R$. dentatus water extract revealed in the phytochemical analysis strongly support the potential of $R$. dentatus to bioreduce $\mathrm{Ag}^{+}$to $\mathrm{Ag}^{\circ}$. Similarly the reducing sugars that are known
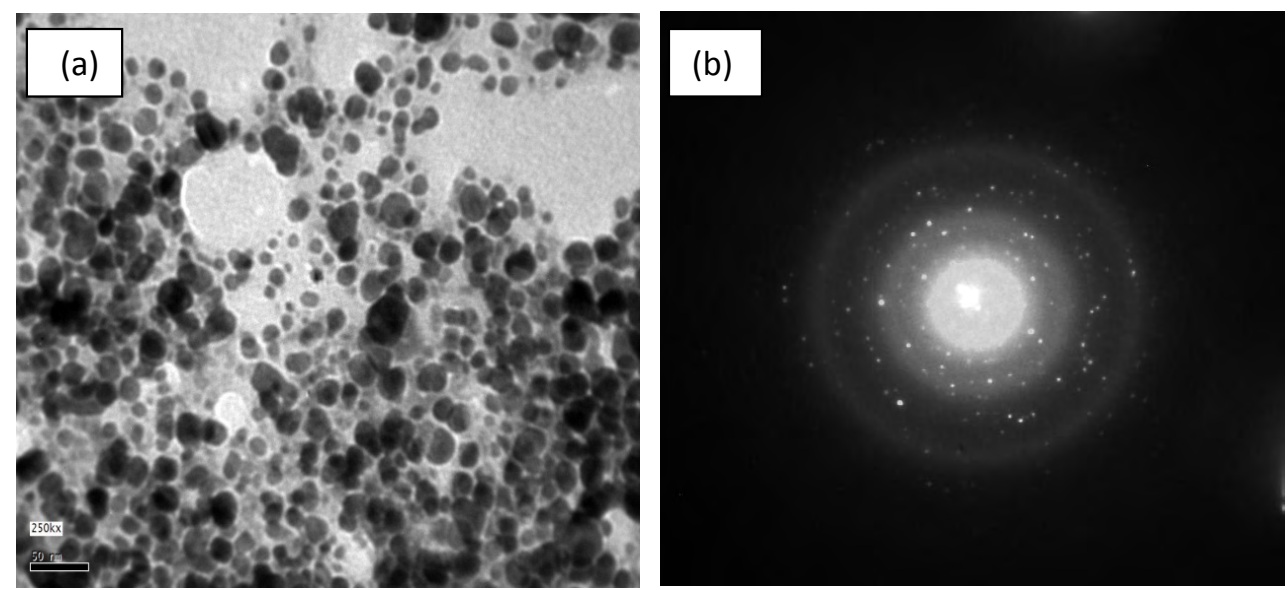

Figure 4: (a) Transmission electron microscopy images of Ag NPs derived from Rumex Dentatus using UV irradiation, (b) Selected area electron diffraction after showing the characteristic crystal planes of elemental silver.

\begin{tabular}{|c|c|c|c|c|c|c|}
\hline \multicolumn{6}{|c|}{ Zone of Inhibition (ZOI) } & \multirow[b]{2}{*}{1 R.D. : $4 \mathrm{AgNO}_{3}$} \\
\hline $\begin{array}{l}\text { Tested Pathogenic Microbial } \\
\text { strains }\end{array}$ & $\begin{array}{l}\text { Rumex dentatus } \\
\text { extract (R. D.) }\end{array}$ & 4 R.D. : $1 \mathrm{AgNO}_{3}$ & 2 R.D. : $1 \mathrm{AgNO}_{3}$ & 1 R.D. : $1 \mathrm{AgNO}_{3}$ & 1 R.D. : $2 \mathrm{AgNO}_{3}$ & \\
\hline Staphylococcus epidermis & 8 & - & 11 & 9 & 13 & 16 \\
\hline Klebsiella pneumonia & 7 & 10 & 9 & 8 & - & 11 \\
\hline Pseudomonas aurignos & - & 9 & 15 & 13 & 23 & 15 \\
\hline Staphylococcus aureus & - & 6 & 13 & 13 & 8 & 10 \\
\hline Shigells spp. & - & 14 & 10 & 10 & 18 & 18 \\
\hline E. coli & 10 & 8 & 9 & 15 & 12 & 20 \\
\hline Staphylococcus biogensis & - & - & - & 14 & 15 & 18 \\
\hline Erwenia carotovora & - & - & 9 & 18 & 2 & 10 \\
\hline Proteus vulgaris & - & 8 & 12 & - & 13 & 13 \\
\hline Fusarium solani & - & - & - & - & - & 7 \\
\hline Asperigillus flaviries & - & - & - & 10 & 9 & 12 \\
\hline Asperigillus ochraceous & - & - & 14 & 13 & 11 & 10 \\
\hline Trichothecium & - & - & - & 14 & 15 & 22 \\
\hline
\end{tabular}

Zone of inhibition, including the diameter of the filter disc $(6.0 \mathrm{~mm})$

Table 1: Antimicrobial activity of the wild $R$. dentatus water extract and the synthesized silver nano particles using mixtures of different ratios of the plant extract and silver nitrate solution using disc diffusion assay. 


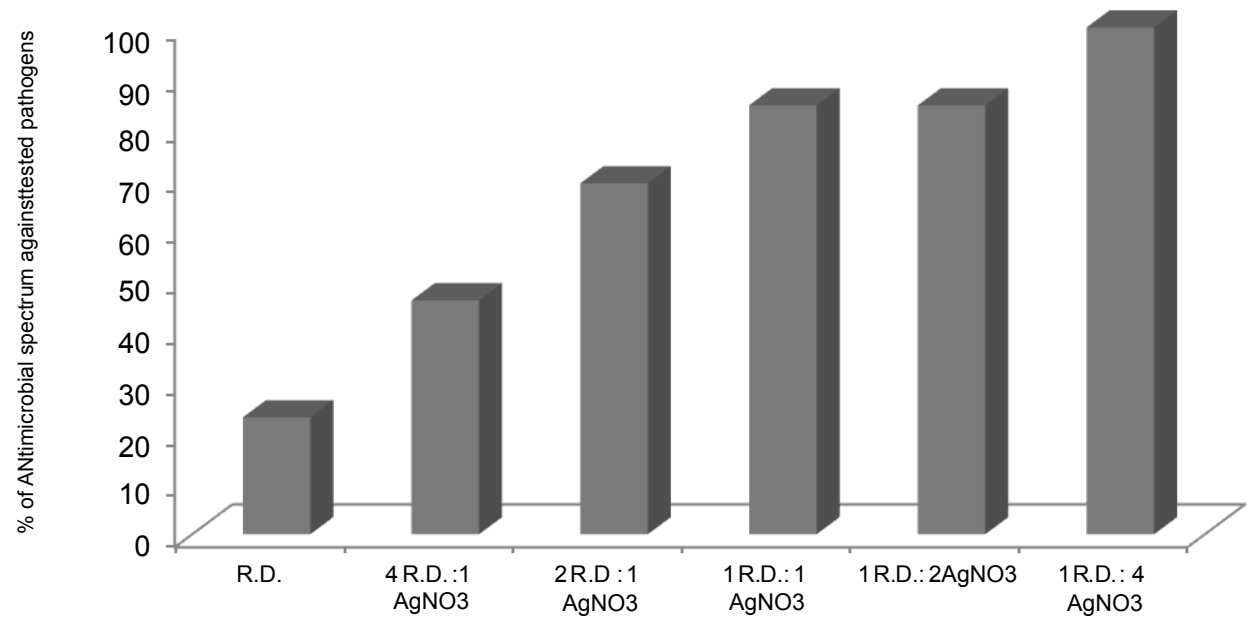

R.D. = Rumex dentatus

Figure 5: \% of the antimicrobial spectrum of $R$. dentatus water extract alone and in combination with different concentrations of $\mathrm{AgNO}_{3}$ from which nanoparticles synthesized against tested pathogenic strains.

to play a vital role in bioreduction were found to be predominant in the extract $[65,67]$. Likewise the non soluble carbohydrate content like starch reflects the capping properties of the extract, and starch is widely used in the synthesis and stabilizing silver nanoparticles [68].

The FTIR absorption spectra offered information regarding chemical changes in the functional groups involved in the bioreduction of precursors and evolution of shape in nanoparticles [65,69].

Silver ion and silver based compounds are highly toxic to microorganisms, showing strong biocidal effect against microbial species because these are highly reactive species with large surface area $[65,70-73]$. Silver nanoparticles produced using plant extracts are known to exhibit antimicrobial activity [74-75]. Antimicrobial activity determined using disc diffusion method confirmed that synthesis of nanoparticles using $R$. dentatus plant extract and UV-irradiation resulted in a greater bactericidal and fungicidal effect with increasing the concentration of the synthesized nano particles on the test pathogens than either the water extract alone or the silver nanoparticles with lower concentration. This experiment provides solid evidence of synergy between $R$. dentatus water extract and silver nanoparticles.

More recently, it was shown that silver (I) chelation prevents unwinding of DNA. Silver nanoparticles are composed of silver (0) atoms $[65,76]$. Silver nanoparticles are larger in size than silver (I) ions, which make them react with more molecules, leading to more antimicrobial activity.

In conclusion, In an attempt to find natural, environmentally benign, and easily available plant-based agents for synthesis of metal nanoparticles, we have demonstrated the efficiency of $R$. dentatus tuber extract in the rapid synthesis of silver nanoparticles possessing a variety of fascinating morphologies owing to its diverse groups of phytochemicals like phenolics, flavonoids, reducing sugars, anthraquinones, sterols, phytoesteryl esters, free fatty acids, chromones and anthrones. Based on our kinetic studies, together with evidence obtained from FTIR, we propose that the main biomolecules responsible for nanoparticles synthesis were polyphenols or flavonoids.

The results of our study show that the combination of silver nanoparticles and water extract of $R$. dentatus had improved antimicrobial efficiency against the tested pathogenic microbes. Overall, this combinational approach seems to be one of the best strategies for therapeutic management in infection control.

\section{References}

1. Ball $P(2002)$ Natural strategies for the molecular engineer. Nanotechnology 13: $15-28$.

2. Roco MC (2003) Broader societal issue of nanotechnology. J Nanopart Res 5: 181-189.

3. Monica RC, Cremonini R (2009) Nanoparticles and higher plants CARYOLOGIA 62: 161-165.

4. Nel A, Xia T, Mädler L, Li N (2006) Toxic potential of materials at the nanolevel. Science 311: 622-627.

5. Brunner TJ, Wick P, Manser P, Spohn P, Grass RN, et al. (2006) In vitro cytotoxicity of oxide nanoparticles: comparison to asbestos, silica, and the effect of particle solubility. Environ Sci Technol 40: 4374-4381.

6. Tiwari DS, Dunn QZ (2009) Photochemistry on a polarisable semi-conductor what do we understand today? J Mater Sci 44: 5063-5079.

7. Samadi-Maybodi A, Nejad-Darzi SK, Akhoondi R (2011) Synthesis and Characterization of Nickel Phosphate Nanoparticles and VSB-5 with Quaternary Ammonium Base. Int. Nano Lett 1: 52-58.

8. Murray CB, Sun S, Doyle H, Betley T (2001) Monodisperse 3d Transition Metal (Co, Ni, Fe) Nanoparticles and Their Assembly into Nanoparticle Superlattices. MRS Bulletin 26: 985-991.

9. Murray R, Rosenthal S, Kobayashi S, Pfaller A (1998) Medical Microbiology 3rd ed. St. Louis: Mosby, p.161.

10. Dai J, Bruening ML (2001) Catalytic nanoparticles formed by reduction of meta ions in multilayered polyelectrolyte films. Nano Lett 2: 497-501.

11. Okuda M, Kobayashi Y, Suzuki K, Sonoda K, Kondoh T, et al. (2005) Selforganized inorganic nanoparticle arrays on protein lattices. Nano Lett 5: 991 993.

12. Xia Y, Xiong Y, Lim B, Skrabalak SE (2009) Shape-controlled synthesis of metal nanocrystals: simple chemistry meets complex physics? Angew Chem Int Ed Engl 48: 60-103

13. Tao A, Kim F, Hess C, Goldberger J, He R, et al. (2003) Langmuir-Blodgett silver nanowire monolayers for molecular sensing using surface-enhanced Raman spectroscopy. Nano Lett 3: 1229-1233. 
Citation: El-Shahaby O, El-Zayat M, Salih E, El-Sherbiny IM, Reicha FM (2013) Evaluation of Antimicrobial Activity of Water Infusion Plant-Mediated Silver Nanoparticles. J Nanomed Nanotechol 4: 178. doi:10.4172/2157-7439.1000178

14. Shiraishi Y, Toshima N (1999) Colloidal silver catalysts for oxidation of ethylene. Mol Catal A Chem 141: 187.

15. Babu SA, Prabu HG (2011) Synthesis of AgNPs using the extract of Calotropis procera flower at room temperature, Mater Lett 65: 1675-1677.

16. Raveendran P, Fu J, Wallen SL (2003) Completely "green" synthesis and stabilization of metal nanoparticles. J Am Chem Soc 125: 13940-13941.

17. Li P, Wang Y, Peng Z, She F, Kong L (2011) Effects of starch nanocrystal on structure and properties of waterborne polyurethane-based composites. Carbohydr Polym 85: 698-703.

18. El-Rafie MH, El-Naggar ME, Ramadan MA, Fouda M, Al-Deyab SS, et al. (2011) Environmental synthesis of silver nanoparticles using hydroxypropyl starch and their characterization. Carbohydr Polym 86: 630-635.

19. Vigneshwaran N, Ashtaputre NM, Varadarajan PV, Nachane RP, Par-Alikar $\mathrm{KM}$, et al. (2007) Biological synthesis of silver nanoparticles using the fungus Aspergillus flavus. Mater Lett 61: 1413-1418.

20. Vigneshwaran N, Kathe AA, Varadarajan PV, Nachane RP, Balsubra-Manya $\mathrm{RH}$ (2011) Synthesis of ecofriendly silver nanoparticle from plant latex used as an important taxonomic tool for phylogenetic interrelationship. Colloids Surf B 53: $55-59$

21. Shahverdi R, Minaeian S, Shahverdi HR, Jamalifar H, Nohi AA (2007) Biosynthesis and application of silver and gold nanoparticles. Process Biochem 42: 919-923.

22. Mandal D, Bolander ME, Mukhopadhyay D, Sarkar G, Mukherjee P (2006) The use of microorganisms for the formation of metal nanoparticles and their application. Appl Microbiol Biotechnol 69: 485-492.

23. Basavaraja S, Balaji SD, Lagashetty A, Rajasab AH, Venkataraman A (2008) Extracellular biosynthesis of silver nanoparticles using the fungus Fusarium semitectum. Mater Res Bull 43: 1164-117.

24. Gardea-Torresdey JL, Gomez E, Peralta-Videa J, Parsons JG, Troiani HE (2002) Formation and growth of Au nanoparticles inside live alfalfa plants. Nano Lett 2: 397-401.

25. Prathna TC, Chandrasekaran NA, Raichur M, Mukherjee A (2011) Kinetic evolution study of silver nanoparticles in bio-based green synthesis process. Colloids Surf A Physicochem Eng Asp 377: 212-216.

26. Rastogi L, Arunachalam J (2011) Sunlight based irradiation strategy for rapid green synthesis of highly stable silver nano particles using aqueous garlic (Allium sativum) extract and their antibacterial potential. Mat Chem Phys 129 558-563.

27. Liu Y, Zhang YA, Zhang M (2010) Green hydrothermal synthesis and characterization of CdO2 nanoparticles. Mat Lett 64: 1779-1781.

28. MubarakAli D, Thajuddin N, Jeganathan K, Gunasekaran M (2011) Plan extract mediated synthesis of silver and gold nanoparticles and its antibacterial activity against clinically isolated pathogens. Colloids Surf B Biointerfaces 85 : 360-365.

29. Vidhu VK, Aromal SA, Philip D (2011) Green synthesis of silver nanoparticles using Macrotyloma uniflorum. Spectrochim Acta A Mol Biomol Spectrosc 83: 392-397.

30. Zhan G, Huang J, Du M, Abdul-Rauf I, Ma Y, et al. (2011) Green synthesis of Au-Pd bimetallic nanoparticles: Single-step bioreduction method with plant extract. Mat Lett 65: 2989-2991.

31. Dubey SP, Lahtinen M, Sillanpää M (2010) Tansy fruit mediated greener synthesis of silver and gold nanoparticles. Process Biochem 45: 1065-1071.

32. Kumar VG, Gokavarapu SD, Rajeswari A, Dhas TS, Karthick V, et al. (2011) Facile green synthesis of gold nanoparticles using leaf extract of antidiabetic potent Cassia auriculata. Colloids Surf B Biointerfaces 87: 159-163.

33. Smitha SL, Philip D, Gopchandran KG (2009) Green synthesis of gold nanoparticles using Cinnamomum zeylanicum leaf broth. Spectrochim Acta A Mol Biomol Spectrosc 74: 735-739.

34. Hernandez JA, Corpas FJ, Gomez M, Del RLA, Sevilla F (1993) Salt-induced oxidative stress mediated by activated oxygen species in pea leaf mitochondria. Physiologia Plantarum 89: 103-110.

35. Radić S, Radić-Stojković M, Pevalek-Kozlina B (2006) Influence of $\mathrm{NaCl}$ and mannitol on peroxidase activity and lipid peroxidation in Centaurea ragusina $\mathrm{L}$. roots and shoots. J Plant Physiol 163: 1284-1292.
36. Hadjichambis ACh, Paraskeva-Hadjichambi D, Della A, Giusti ME, De Pasquale C, et al. (2008) Wild and semi-domesticated food plant consumption in seven circum-Mediterranean areas. Int J Food Sci Nutr 59: 383-414.

37. Hawas UW, Ahmed EM, Abdelkader AF, Taie HA (2011) Biological activity of flavonol glycosides from Rumex dentatus plant, an Egyptian Xerophyte. Journal of Medicinal Plants Research 5: 4239-4243.

38. Elzaawely ST, Abdelghany A (2012) Antioxidant Capacity and Phenolic Content of Rumex dentatus L. Grown in Egypt. J Crop Sci Biotechnol 15: 59-64.

39. Fatima N, Zia M, Rizvi1 ZF, Ahmad S, Mirza B, et al. (2009) Biological activities of Rumex dentatus L: Evaluation of methanol and hexane extracts. Afr. J. Biotechnol 8: 6945-6951.

40. Hameed I, Dastagir G (2009) Nutritional analyses of Rumex hastatus D. Don Rumex dentatus Linn and Rumex nepalensis. Spreng. Afr. J. Biotechnol 8 : 4131-4133.

41. Hussain F, Mobeen F, Kil B, Yoo SO (1997) Allelopathic suppression of wheat and mustard by Rumex dentatus ssp. klotzschianus. J. Plant Biol 40: 120-124.

42. Hussain F, Ahmad B, Hameed I, Dastagir G, Sanaullah P, et al. (2012) Antibacterial, antifungal and insecticidal activities of some selected medicinal plants of Polygonaceae. Afr. J. Biotechnol 9: 5032-5036.

43. Liu SY, Sporer F, Wink M, Jourdane J, Henning R, et al. (1997) Anthraquinones in Rheum palmatum and Rumex dentatus (Polygonaceae), and phorbol esters in Jatropha curcas (Euphorbiaceae) with molluscicidal activity against the schistosome vector snails Oncomelania, Biomphalaria and Bulinus. Trop Med Int Health 2: 179-188.

44. Süleyman H, Demirezer LO, Kuruüzüm A, Banoğlu ZN, Göçer F, et al. (1999) Antiinflammatory effect of the aqueous extract from Rumex patientia L. roots. J Ethnopharmacol 65: 141-148

45. Litvinenko YA, MuzychKina RA (2003) Phytochemical investigation of biologically active substances in certain Kazakhstan Rumex species. Chemistry of Natural Compounds 5: 368-370.

46. Umer A, Yousaf Z, Khan F, Hussain U, Anjum A, et al. (2010) Evaluation of allelopathic potential of some selected medicinal species. Afr. J. Biotechnol 9 : 6194-6206.

47. Chinese Herbs (1999) State Administration of Traditional Chinese Medicine of China, Shanghai Science and Technology Press, Shanghai, 6: 722.

48. Saleh NAM, El-Hadidi MN, Arafa RFM (1993) Flavonoids and Anthraquinones of some Egyptian Rumex species (Polygonaceae). Biochem Syst Ecol 21: 301 303.

49. Tamano M, Koketsu J (1982) Isolation of Hydroxyanthrones from the Roots of Rumex acetosa Linn. Agric. Biol. Chem 46: 1913-1914.

50. Zhu JJ, Zhang CF, Zhang M, Wang ZT (2006) [Studies on chemical constituents in roots of Rumex dentatus]. Zhongguo Zhong Yao Za Zhi 31: 1691-1693.

51. Boulos L (2005) Flora of Egypt. Al-Hadara Publication 4: 617.

52. Wolfe K, Wu X, Liu RH (2003) Antioxidant activity of apple peels. J Agric Food Chem 51: 609-614.

53. Zhishen J, Mengcheng T, Jianming W (1999) Research on antioxidant activity of flavonoids from natural materials. Food Chem 64: 555-559.

54. Kitts DD, Wijewickreme AN, Hu C (2000) Antioxidant properties of a North American ginseng extract. Mol Cell Biochem 203: 1-10.

55. Liyana-Pathirana CM, Shahidi F (2005) Antioxidant activity of commercial soft and hard wheat (Triticum aestivum L.) as affected by gastric $\mathrm{pH}$ conditions. J Agric Food Chem 53: 2433-2440.

56. Parejo I, Codina C, Petrakis C, Kefalas P (2000) Evaluation of scavenging activity assessed by $\mathrm{Co}(\mathrm{II}) / \mathrm{EDTA}$-induced luminol chemiluminescence and $\mathrm{DPPH}^{*}$ (2,2-diphenyl-1-picrylhydrazyl) free radical assay. J Pharmacol Toxicol Methods 44: 507-512.

57. Thayumanavan B, Sadasivam S (1984) Physicochemical basis for preferentia uses of certain rice varieties. Qual Plant Foods Hum Nutr 34: 253-259.

58. Sardari A, Gholamreza M, Daneshtalab M (1998) Phytopharmaceuticals. Part 1: Antifungal Activity of Selected Iranian and Canadian Plants. Pharm Biol 36 180-188.

59. Aberoumand A, Deokule SS (2008) Comparison of Phenolic Compounds of Some Edible Plants of Iran and India. Pakistan Journal of Nutrition 7: 582-585. 
Citation: El-Shahaby O, El-Zayat M, Salih E, El-Sherbiny IM, Reicha FM (2013) Evaluation of Antimicrobial Activity of Water Infusion Plant-Mediated Silver Nanoparticles. J Nanomed Nanotechol 4: 178. doi:10.4172/2157-7439.1000178

60. Maestri DM, Nepote V, Lamarque AL, Zygadlo JA (2006) Natural products as antioxidants. Phytochemistry: Advances in Research 105-135.

61. Sanchez-Moreno C, Larrauri JA, Saura-Calixto F (1998) A procedure to measure the antiradical efficiency of polyphenols. J. Sci. Food Agric 76: 270 276

62. Spranger I, Sun B, Mateus AM, de Freitas V, Rsicardo-da-Silva J (2008) Chemical characterization and antioxidant activities of oligomeric and polymeric procyanidin fractions from grape seeds. Food Chemistry 108: 519-532.

63. Pileni MP (2006) Reverse micelles used as templates: a new understanding in nanocrystal growth. Journal of experimental nanoscience 1: 13-27.

64. Shankar SS, Rai A, Ahmad A, Sastry M (2004) Rapid synthesis of Au, Ag, and bimetallic Au core-Ag shell nanoparticles using Neem (Azadirachta indica) leaf broth. J Colloid Interface Sci 275: 496-502.

65. Ghosh S, Patil S, Ahire M, Kitture R, Kale S, et al. (2012) Synthesis of silver nanoparticles using Dioscorea bulbifera tuber extract and evalution of its synergistic potential in combination with antimicrobial agents. Int $\mathrm{J}$ Nanomedicine. 7: 483-496.

66. Egorova EM, Revina AA (2000) Synthesis of metallic nanoparticles in reverse micelles in the presence of quercetin. Colloids Surf A Physicochem Eng Asp 168: 87-96.

67. Panigrahi S, Kundu S, Ghosh SK, Nath S, Pal T (2004) General method of synthesis for metal nanoparticles. J Nanopart Res 6: 411-414.

68. Sharma VK, Yngard RA, Lin Y (2009) Silver nanoparticles: green synthesis and their antimicrobial activities. Adv Colloid Interface Sci 145: 83-96.
69. Socrates G (2001) Infrared and Raman Characteristic Group Frequencies. 3rd ed. Chichester (UK): John Wiley \& Sons Ltd.

70. Dibrov P, Dzioba J, Gosink KK, Häse CC (2002) Chemiosmotic mechanism of antimicrobial activity of $\mathrm{Ag}(+)$ in Vibrio cholerae. Antimicrob Agents Chemother 46: 2668-2670.

71. Suvorova E, Klechkovskaya VV, Kopeikin VV, Buffat PA (2005) Stability of Ag nanoparticles dispersed in amphiphilic organic matrix. J Cryst Growth 275 : e2351-e2356.

72. Paknikar KM (2007) Antimicrobial activity of biologically stabilized silver nanoparticles, United States Patent US 2007/0218555A1.

73. Shahverdi AR, Fakhimi A, Shahverdi HR, Minaian S (2007) Synthesis and effect of silver nanoparticles on the antibacterial activity of different antibiotics against Staphylococcus aureus and Escherichia coli. Nanomedicine 3: 168171.

74. Nabikhan A, Kandasamy K, Raj A, Alikunhi NM (2010) Synthesis of antimicrobial silver nanoparticles by callus and leaf extracts from saltmarsh plant, Sesuvium portulacastrum L. Colloids Surf B Biointerfaces 79: 488-493.

75. Savithramma N, Linga Rao M, Rukmini K, Suvarnalatha P (2011) Antimicrobia activity of Silver Nanoparticles synthesized by using Medicinal Plants, International Journal of ChemTech Research 3: 1394-1402.

76. Batarseh KI (2004) Anomaly and correlation of killing in the therapeutic properties of silver (I) chelation with glutamic and tartaric acids. J Antimicrob Chemother 54: 546-548. 